University of Nebraska - Lincoln

DigitalCommons@University of Nebraska - Lincoln

\title{
Evaluating the Efficacy of Adaptive Management Approaches: Is There a Formula For Success?
}

Jamie E. McFadden

University of Nebraska-Lincoln, jmcfadden@huskers.unl.edu

Tim L. Hiller

University of Nebraska-Lincoln, tithiller@CFR.MsState.Edu

Andrew J. Tyre

University of Nebraska at Lincoln, atyre2@unl.edu

Follow this and additional works at: https://digitalcommons.unl.edu/natrespapers

Part of the Natural Resources and Conservation Commons, and the Population Biology Commons

McFadden, Jamie E.; Hiller, Tim L.; and Tyre, Andrew J., "Evaluating the Efficacy of Adaptive Management Approaches: Is There a Formula For Success?" (2011). Papers in Natural Resources. 302.

https://digitalcommons.unl.edu/natrespapers/302

This Article is brought to you for free and open access by the Natural Resources, School of at DigitalCommons@University of Nebraska - Lincoln. It has been accepted for inclusion in Papers in Natural Resources by an authorized administrator of DigitalCommons@University of Nebraska - Lincoln. 


\title{
Evaluating the efficacy of adaptive management approaches: Is there a formula for success?
}

\author{
Jamie E. McFadden, Tim L. Hiller, and Andrew J. Tyre \\ School of Natural Resources, University of Nebraska-Lincoln \\ Corresponding author - A. J. Tyre, School of Natural Resources, University of Nebraska-Lincoln, 3310 Holdrege St., \\ 416 Hardin Hall, Lincoln, NE 68583-0974, USA; tel 402 472-4054, fax 402 472-2946 \\ Email addresses - J. E. McFadden, jmcfadden@huskers.unl.edu ; T. L. Hiller, timothy.1.hiller@state.or.us ; A. J. Tyre, atyre2@unl.edu \\ Present address of T. L. Hiller - Oregon Department of Fish and Wildlife, Wildlife Division, Salem, OR 97303-4924
}

\begin{abstract}
Within the field of natural-resources management, the application of adaptive management is appropriate for complex problems high in uncertainty. Adaptive management is becoming an increasingly popular management-decision tool within the scientific community and has developed into two primary schools of thought: the Resilience-Experimentalist School (with high emphasis on stakeholder involvement, resilience, and highly complex models) and the Decision-Theoretic School (which results in relatively simple models through emphasizing stakeholder involvement for identifying management objectives). Because of these differences, adaptive management plans implemented under each of these schools may yield varying levels of success. We evaluated peer-reviewed literature focused on incorporation of adaptive management to identify components of successful adaptive management plans. Our evaluation included adaptive management elements such as stakeholder involvement, definitions of management objectives and actions, use and complexity of predictive models, and the sequence in which these elements were applied. We also defined a scale of degrees of success to make comparisons between the two adaptive management schools of thought. Our results include the relationship between the adaptive management process documented in the reviewed literature and our defined continuum of successful outcomes. Our data suggest an increase in the number of published articles with substantive discussion of adaptive management from 2000 to 2009 at a mean rate of annual change of 0.92 $\left(r^{2}=0.56\right)$. Additionally, our examination of data for temporal patterns related to each school resulted in an increase in acknowledgement of the Decision-Theoretic School of thought at a mean annual rate of change of $0.02\left(r^{2}=0.6679\right)$ and a stable acknowledgement for the Resilience-Experimentalist School of thought $\left(r^{2}=0.0042\right.$; slope $\left.=0.0013\right)$. Identifying the elements of successful adaptive management will be advantageous to natural-resources managers considering adaptive management as a decision tool.
\end{abstract}

Keywords: adaptive management, structured decision-making, resilience, uncertainty

\section{Introduction}

Natural-resources managers are faced with value-laden decisions high in complexity, risk, and uncertainty (Levin, 1999; Gunderson and Holling, 2002; Berkes, 2004). The application of conventional research methods is often insufficient to support effective decision-making under these circumstances, particularly when decisions must be made regardless of the level of knowledge or uncertainty. There is a critical need to improve how research is incorporated into management decisions where uncertainty places limitations on contributions of science (Reynolds et al., 1996; Lee and Bradshaw, 1998; Berg et al., 1999; Robertson and Hull, 2001). Complex decisions involving risk in business and economics are often approached using structured decision-making (SDM), described by proponents as "a formalization of common sense for situations too complicated for the informal use of common sense" (Keeney, 1982, p. 806).Although such formal decision-making skills may be underdeveloped by natural-resources managers, the use of SDM is becoming more prevalent within the field of natural resources (Gregory and Keeney, 2002; Conroy et al., 2008; Gregory and Long, 2009). By repeating decisions within an SDM approach, natural-resources managers can learn through an ongoing process of implementing various management actions, monitoring management outcomes, and updating ecological models by comparing actual outcomes with expected outcomes (Hilborn and Walters, 1981; 
Walters, 1986; Williams, 1996; Carpenter, 2002; Johnson et al., 2002). This ongoing (i.e., iterative) learning process, learning by doing, is known as adaptive management.

Throughout the development of natural-resources management, research, and monitoring, natural-resources managers have experienced numerous advancements in monitoring and research methods. There remains a need to further improve and develop the tools for decision making that integrate an active-learning process (Walters and Holling, 1990; Walters, 1997). Though there appears to be reluctance by some natural-resources managers to use adaptive management (Blumstein, 2007), it is becoming an increasingly popular concept and has developed within several governmental agencies, resulting in varying definitions of the process. However, there are commonalities amongst the various agencies regarding the adaptive management process, including establishing an iterative process that involves sharing of responsibilities and decision making among managers, biologists, and stakeholders (Ruitenbeek and Cartier, 2001). These decision-makers collaborate to develop management plans that allow for analyses of large-scale ecosystem problems through implementing various management actions based on appropriate measurable objectives (Walters, 1997; Holling, 2001; Hughes et al., 2007). However, adaptive management may result in variable degrees of success (Walters, 1997). For natural resources managers, it is important to improve understanding of the adaptive management process by identifying correlates of success within the available adaptive management literature. We can also apply active learning by doing to the particular adaptive management approaches that have been implemented (Johnson, 2006; Runge et al., 2006; Williams et al., 2007). In other words, we need to "adaptively manage" the field of adaptive management by testing different decision-making and modeling approaches, monitoring these management outcomes, and changing our practices to deliver better management outcomes.

Overall, there are two dominant adaptive management schools of thought (Figure 1) which most adaptive management plans and approaches seem to follow: the Resilience-Experimentalist Adaptive Management School which originates from the work of Gunderson et al. (1995), and the Decision-Theoretic Adaptive Management School exemplified by Possingham et al. (2001) and the U.S. Department of Interior (Williams et al., 2007). Management of the Florida Everglades (Walters et al., 1992; Milon et al., 1997; Gunderson, 2000; Gunderson and Light, 2006) and the Glen Canyon Dam Adaptive Management Program (Walters and Holling, 1990; Lee, 1999; Meretsky et al., 2000; Pulwarty and Theodore, 2001) are well-known examples of the implementation of the Resilience-Experimentalist Adaptive Management School. In this school, there is high emphasis placed on obtaining a shared understanding among stakeholders of the system during the entire process, especially before

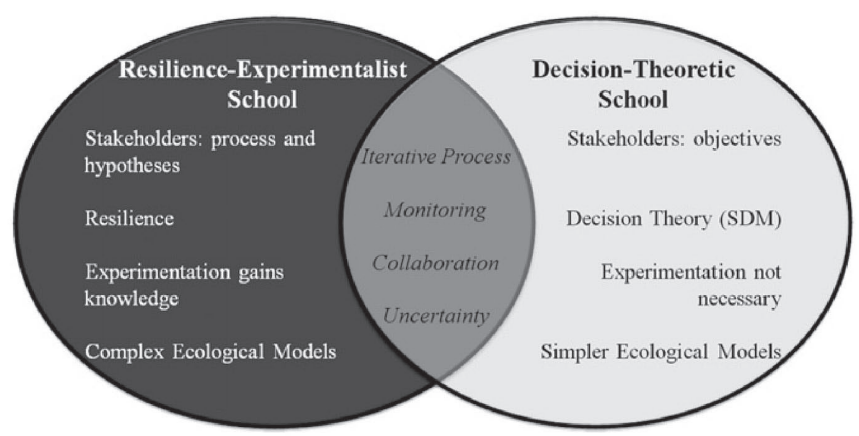

Figure 1. A comparison of the two dominant adaptive management schools of thought: the Resilience-Experimentalist Adaptive Management School and the Decision-Theoretic Adaptive Management School. defining objectives and management actions. In addition, proponents of this school also require active learning about ecosystem resilience, i.e., the capacity of an ecosystem to remain within its current state or return to its original state following perturbation (Walters, 1997; Holling, 2001; Hughes et al., 2007).

Alternatively, the Decision-Theoretic School, more heavily influenced by decision theory, also stresses communication among stakeholders, but communication is focused on defining the management problem, objectives, and actions prior to developing process models. The North American Waterfowl Management Plan (Johnson et al., 1993; Johnson and Williams, 1999; Nichols et al., 2007) and conservation of red knots (Calidris canutus) and horseshoe crabs (Limulus polyphemus) in Delaware Bay (McGowan et al., 2009) are examples of the DecisionTheoretic School where decision theory approaches have been incorporated into the adaptive management process. These differences may appear minor, but the process for the Decision-Theoretic School often leads to less complex ecological models that are centered on the decision problem (e.g., Conroy et al., 2008), whereas the process for the Resilience-Experimentalist School leads to complex ecological models that include all potentially significant details of the ecosystem (e.g., Davis et al., 1994; Light and Dineen, 1994).

There are many organizations that promote adaptive management in ways that are broadly consistent with each school of thought (Table 1). The Adaptive Environmental Assessment and Management process (Holling, 1978), Collaborative Adaptive Management Network (2004), Sustainable Ecosystems Institute (2007), and Foundations of Success (2009) generally appear to follow the Resilience-Experimentalist School. The process of Adaptive Environmental Assessment and Management focuses on understanding dynamic environmental systems through developing computer simulations under multiple management actions (Holling, 1978; Gunderson et al., 1995; Blann and Light, 2000). Similarly, the involvement of the Collaborative Adaptive Management Network in the management process is to facilitate adaptive management decisions, promote integrity and improved learning through collaboration of expertise, and serve as a primary role in adaptive management training of skilled managers in the field. The application of these various aspects of the Collaborative Adaptive Management Network results in an increase in learning and efficacy of management plans. The Sustainable Ecosystems Institute and Foundations of Success have similar roles in working with natural-resources agencies to develop adaptive management-based tools and decision-making strategies for providing natural resources managers with problem-specific related facilitation, advising, and training services for individuals and organizations in need.

The seven steps of SDM developed by Possingham (2000) and Williams et al. (2007) are examples of the Decision-Theoretic school of thought. Possingham et al. (2001) included monitoring and analysis of implemented management actions within the SDM process. Here, the SDM process is designed to aid managers by developing ecological models to predict which action is best within the set of actions available. Under this approach, natural-resources managers are provided with a method for prioritization of objectives and actions based on consequences of decisions and tradeoffs among objectives and active learning is achieved by requiring ongoing testing and re-evaluation of previous decisions. Similarly, in developing an Adaptive Management Technical Guide and problem-scoping key, the Department of Interior provides aid for identification of appropriate problems and implementation of adaptive management (Williams et al., 2007).

Despite the differences between schools discussed above, a recurrent theme in all adaptive management approaches is the ongoing monitoring of measurable objectives while also imple- 
Table 1. Comparison of five selected decision-making methods within the adaptive management literature including Gunderson's et al. (1995) Adaptive Environmental Assessment and Management (AEAM), Possingham's (2000) Structured decision-making (SDM), Collaborative Adaptive Management Network (CAMNet, 2004), Department of Interior (DOI) Adaptive Management (AM) Protocol from the DOI AM Technical Guide (Williams et al., 2007), and Foundations of Success (FOS) with the Sustainable Ecosystems Institute (SEI, 2007). Comparison criteria include nine adaptive management related variables found from adaptive management literature along where variables were ordered (i.e. Order of Variables) according to their sequence within each decision-making method.

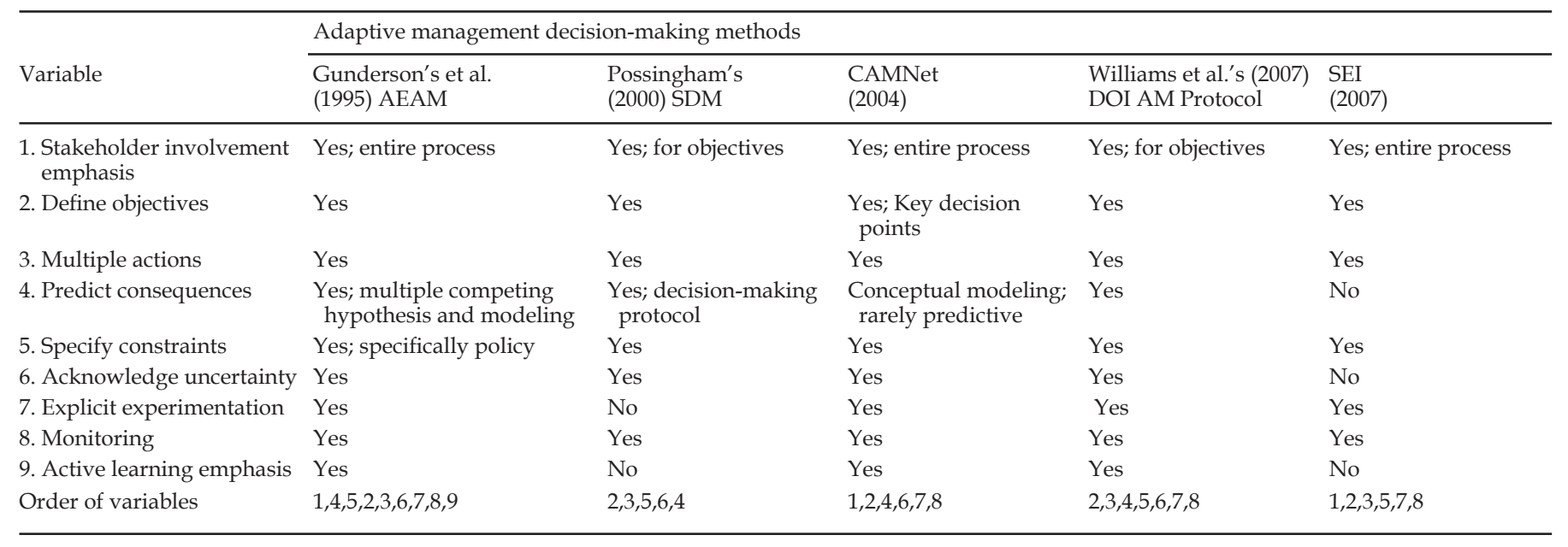

menting selected actions (Walters and Holling, 1990; Field et al., 2004; Gerber et al., 2005). With active learning and continuous monitoring, uncertainty decreases and forecast management outcomes are more easily predicted (Walters, 1986, 1997). This allows for more informed decision making as the number of iterations increase in the adaptive management process.

While promotion of individual approaches to adaptive management occurs, there is no comparative overview of different adaptive management approaches (i.e., schools of thought). Scientific literature acknowledges that for the successful application of adaptive management, there must be a cumulative experience of the process through building a thorough understanding of the various elements (Gerber et al., 2007). Overall, with multiple approaches emphasizing different elements, it is imperative that managers fully understand their needs and desired outcomes on a project-level basis. When managers are faced with many requirements, responsibilities, and other external pressures, they require a method with a high level of efficacy that incorporates decision-making tools and adaptive management as a sustained active-learning process. Our objective was to assess the two dominant adaptive management schools of thought in the literature to determine which approach is applied most successfully based on our a priori set of criteria. We related the success of each case study described in the literature to their assigned adaptive management approach (i.e., Decision-Theoretic, ResilienceExperimentalist, Other). Our goal was to increase efficacy of adaptive management approaches for natural-resources management by investigating the correlations among process, success, and efficacy of each approach.

\section{Methods}

We searched a selection of peer-reviewed literature for published case studies incorporating adaptive management approaches to evaluate how successful outcomes vary by adaptive management school of thought. We selected eight scientific journals in the top ranks of ecology, conservation biology, and fisheries and wildlife management. We searched all articles from 2000 to 2009, unless limited to a shorter period by access, within The Journal of Wildlife Management, Ecology, Conservation Biology, Conservation Ecology (2000-2003), Ecological Applications, Journal of Applied Ecology, Wildlife Research (2008-
2009), and Canadian Journal of Fisheries and Aquatic Sciences. In selecting case studies for review, we required an article to contain the term "adaptive management" within the document text. For our analysis of all adaptive management articles, we used a linear regression to describe the relationship of adaptive management articles as a function of time and the coefficient of determination $\left(r^{2}\right)$ to quantify the model fit.

To evaluate the success of different adaptive management schools of thought, we first defined success. The MerriamWebster dictionary defines success as "a favorable or desired outcome" (Merriam-Webster, 2010). In applying these definitions to the adaptive management process, there can be a wide range of outcomes considered successful. For example, Plan A may be more successful than Plan B if Plan A engaged in more active learning through implementing management actions over several years. Alternatively, Plan A may be less successful if only Plan B met its specified objectives. Formal analysis of a decision problem, meeting objectives, engaging in active learning, and implementing management actions are all vital steps during the adaptive management process. In arriving at a definition for success, we can ask four questions: Was an explicit formal analysis of the decision conducted? Does the resulting management plan include an iterative cycle? Was a management action implemented? Did the implemented action achieve the desired outcome? For our purposes, we acknowledge that there is a range of "successful" adaptive management up to and including achieving objectives and implementing actions from which we can learn.

We described five hierarchical categories (Mention, Theory, Suggest, Framework, and Implement) and divided articles according to the extent to which adaptive management was implemented based on information within each article. The Mention category included articles that used adaptive management merely as a catch phrase; these were not directly included in the analysis. The Theory category included articles discussing adaptive management in a general theoretical context about the application of adaptive management practices, but which lacked a description of a specific case study. The Suggest category included articles acknowledging adaptive management as an appropriate approach for a particular management problem or management practice, but that did not provide a complete analysis of a specific problem. The Framework category described articles that, in addition to ac- 


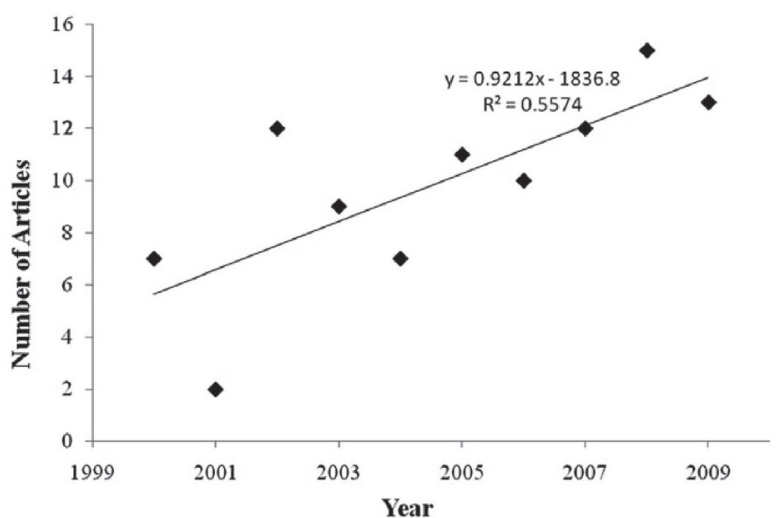

Figure 2. Number of scientific articles that reference the term adaptive management ( $n=96$; not including the Mention articles) from eight scientific journals by year from 2000 to 2009. Linear regression suggested a slope of 0.92 and $r^{2}=0.56$.

knowledging adaptive management as an appropriate approach, provided a decision-based framework for a specific management problem. The Implement category described articles where a management action was implemented, the outcome monitored, and the results incorporated into the next management decision. This category also included articles where improvements were incorporated to an existing adaptive management framework. We assigned articles to the category Against if they deemed adaptive management an inappropriate approach for their management problem.

Case studies categorized as Framework or Implement articles were required to have stated objectives relevant to adaptive management, and have more than one management action to choose from for implementation. We established a list of variables found in the articles used for decision-making and management, including measurable objectives, defined actions, stakeholder involvement, forecasted consequences, legal obligation, and action implementation. We defined these variables and the order in which they appeared throughout the adaptive management process for each case study. To compare case studies further, we identified the most appropriate school of thought for each based on original descriptions of each approach (e.g., Gunderson et al., 1995; Possingham, 2000). Using the average number of case studies per success category, we obtained the mean level of success for each approach. For our analysis of success categories, we used a linear regression to describe the relationship of the proportion of articles in each success category as a function of time and the coefficient of determination $\left(r^{2}\right)$ to quantify the model fit. We used similar methods for our analysis of schools of thought where the proportion of articles in a school of thought is a function of time. To evaluate the relationship between success and a specific adaptive management school, we identified patterns of adaptive management variables within both schools that yielded similar levels of success.

\section{Results}

We identified 96 scientific articles from eight scientific journals with some substantive reference of the term adaptive management and found a basic temporal trend regarding discussion of adaptive management (Figure 2). Our data showed an increase in number of published articles with substantive discussion of adaptive management from 2000 to 2009 at a mean rate of annual change of $0.92\left(r^{2}=0.5574\right)$, or about one article per year. Of our reviewed literature, we assigned $18 \%$ $(n=17)$ of articles to Theory, $42 \%(n=40)$ to Suggest, $24 \%(n=$ $23)$ to Framework, $14 \%(n=13)$ to Implement, and $3 \%(n=3)$

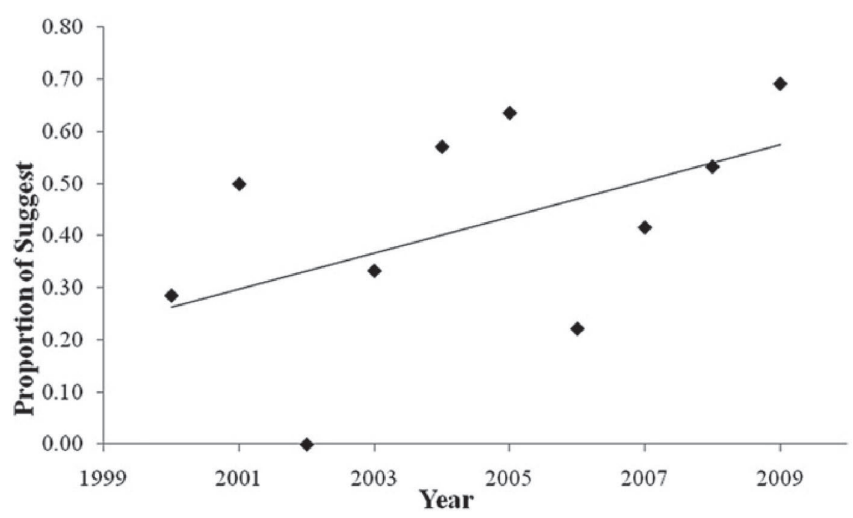

Figure 3. The percentage of scientific articles in the suggest category over time from 2000 to 2009. Linear regression suggested a slope of $m$ $=0.0346$ and $r^{2}=0.2442$.

to Against. The number of published articles that reported implementation of management actions within an adaptive management framework was low (24\%) within our selected journals and years. In addition, we found three articles advising against the general concept of adaptive management, usually suggesting that adaptive management was not a practical approach for their particular study. For a complete list of our reviewed literature by school of thought and success category refer to Appendix A in the supplemental material.

We found unique trends for each success category, particularly for Theory and Suggest categories, over time. For Theory, we observed a slight decrease in the proportion of articles discussing adaptive management in concept at a mean annual rate of change of $\_0.02$ over the last ten years $\left(r^{2}=0.1907\right)$, but found an increase in the proportion of articles in the Suggest category at a mean rate of annual change of $0.03\left(r^{2}=0.2442\right.$; Figure 3). There was no conclusive trend in the percentage of the Framework $\left(r^{2}=0.0026 ; m=0.003\right)$ and Implement $\left(r^{2}=\right.$ $0.0238 ; m=\_0.0076$ ) categories since 2000 .

After we sub-divided each category into the two schools of thought, we assigned 20\% (n=9) of articles to Theory, 39\% ( $n$ $=18)$ to Suggest, $30 \%(n=14)$ to Framework, and $11 \%(n=5)$ to Implement within the Resilience-Experimentalist School of Thought (Figure 4). We assigned $0 \%(n=2)$ of articles to Theory, $26 \%(n=6)$ to Suggest, $35 \%(n=8)$ to Framework, and $30 \%(n=7)$ to Implement within the Decision-Theoretic School of Thought. Our examination of data for temporal patterns related to each school resulted in an increase in acknowledgement of the Decision-Theoretic School of thought at a mean annual rate of change of $0.02\left(r^{2}=0.6679\right)$ and a stable acknowledgement for the Resilience-Experimentalist School of thought $\left(r^{2}=0.0042 ; m=0.0013\right.$; Figure 5).

\section{Discussion}

Based on our results, we have evidence that the amount of published literature related to adaptive management has increased over the last decade, at least within the limited set of selected journals. In addition, the increase was not uniform among success categories. We originally expected the Theory and Suggest articles to decrease and the Framework and Implement articles to increase over time as an indication of increased acceptance and use of adaptive management. However, although Theory articles slightly decreased over time, the observed increase was in Suggest articles rather than Framework or Implement. It appears the current movement of adaptive management in practice is from discussion in a conceptual sense to a realization of the tool being useful in a prac- 


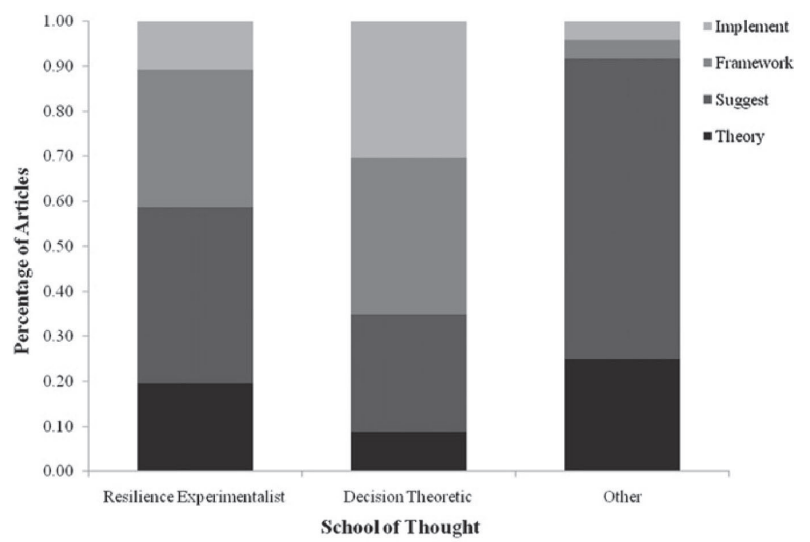

Figure 4 . The percentage of scientific articles by success category for the Resilience-Experimentalist School of Thought $(20 \%(n=9)$ to Theory, $39 \%(n=18)$ to Suggest, $30 \%(n=14)$ to Framework, and $11 \%$ $(n=5)$ to Implement), the Decision-Theoretic School of Thought $(0 \%$ $(n=2)$ to Theory, $26 \%(n=6)$ to Suggest, $35 \%(n=8)$ to Framework, and $30 \%(n=7)$ to Implement), and other $(25 \%(n=6)$ to Theory, $67 \%(n=16)$ to Suggest, $0 \%(n=1)$ to Framework, and $0 \%(n=1)$ to Implement).

tical manner, but perhaps not yet to implementation. This suggests that the amount of time for theory to reach practice may be longer than the period of our analysis. While managers in the field of natural-resources generally acknowledge adaptive management as an appropriate approach for managing complex ecosystems, the managers may experience difficulty in proceeding with the adaptive management process to the implementation stage. As suggested by Hobbs and Hilborn (2006), one difficulty in applying adaptive management in its original design by Holling (1978) lies in a lack of natural-resources researchers and managers trained in SDM, adaptive management, maximum likelihood, and Bayesian methods (Powell et al., in press). Alternatively, it may be that successful implementations do not generate publishable articles, either because of a lack of interest on the part of managers in publishing, or because journal editors and referees do not regard such articles as worthy of publication.

The distribution of articles among categories differed for each school. Numerically, the Resilience-Experimentalist School contained more Suggest and Framework articles than the Decision- Theoretic School, but proportionally, the Decision-Theoretic School had more Framework and Implement articles than Suggest articles. The difference between the distributions of categories for each school may show that the Decision-Theoretic School is easier to use for developing frameworks for natural-resources management.

It appears the Decision-Theoretic School provides a framework more conducive to implementing a management action than the Resilience-Experimentalist School, as there were proportionally more Implement articles under the Decision-Theoretic School. The frameworks developed under the DecisionTheoretic School may result in higher efficacy because the Decision-Theoretic framework utilizes simple models to make decisions (Possingham et al., 2001). In turn, increased efficacy in the process may lead to an easier documentation process explaining the higher percentage of Framework and Implement articles for the Decision-Theoretic School.

An equally important difference, experimentation, may also yield higher difficulty in management implementation for those following the Resilience-Experimentalist School; in particular, the risk that an experiment will fail to achieve the management objective is a substantial barrier to achieving management implementation (Gregory et al., 2006). According to the

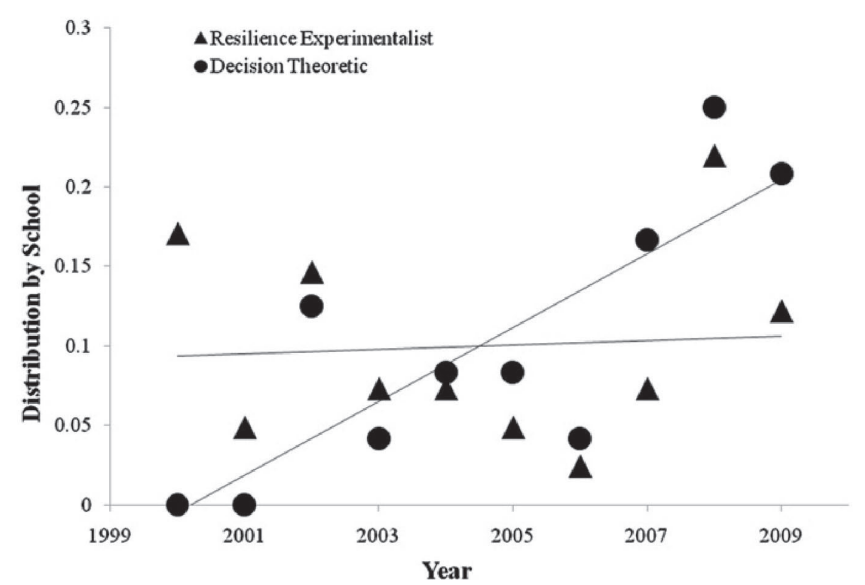

Figure 5. The percentage of scientific articles with some reference of the term adaptive management (not including the Mention articles) from eight scientific journals by year from 2000 to 2009 categorized by two adaptive management schools, the Resilience-Experimentalist with $r^{2}=0.00 ; m=0.0013 ; n=10$ (41 total articles) and the DecisionTheoretic with $r^{2}=0.67 ; m=0.0232 ; n=10$ (24 total articles).

Decision-Theoretic School, experiments are not required, but can be replaced with tradeoff analysis in situations where it is difficult to implement controlled experiments in large-scale ecosystems (McCarthy and Possingham, 2007). While the exact mechanism causing such a difference between schools regarding number of Framework articles is unknown, recent case studies demonstrate multiple barriers to management implementation success. Such barriers include modeling difficulties, institutional rigidity, high financial costs, stakeholder dissention, and high political risks (Hilborn and Walters, 1981; Walters, 1997; Gunderson, 1999; Sutherland, 2006).

Our findings may be biased to some extent by our definitions of adaptive management and success. Given the vague linguistic nature of some literature reviewed for our study, the categorization of case studies is and must be subjective to some degree. Additionally, we looked at relatively broad definitions of schools of thought because each approach may evolve by some unknown, but probably small, rate. We assumed that the broad framework within each school did not evolve enough through time to affect our results, which covered a relatively short period (2000e2009).

\section{Conclusion}

Scientific literature acknowledges that successful application of adaptive management requires building a thorough understanding of the various elements of the process through cumulative experience (Gerber et al., 2007). Our study takes the first meta-analytical perspective on adaptive management, explicitly recognizing and comparing different approaches and definitions of the process. Regardless of the challenge of publishing adaptive-management work that is applied in comparison to theoretical, we may see a longer delay in published works categorized as Framework and Implement due to the time scale of implementing adaptive management given the slow transfer of technology. If adaptive management is to improve as an approach to management under uncertainty, it is imperative to study the process of adaptive management itself, including all approaches. Our study evaluated two dominant schools of thought in the adaptive management field and showed that adaptive management as a concept continues to evolve through shifts in the dominant school of thought, as well as gain greater acceptance as a possible framework for management. 
Acknowledgements - We thank C. R. Allen, K. L. Pope, and J. J. Fontaine for the invitation to participate in this special issue of the Journal of Environmental Management devoted to Adaptive Management of Natural Resources and their constructive comments on this manuscript. We thank T. Awada, the Tyre lab members, M. Conroy, W. Thogmartin, and two anonymous reviewers for Journal of Environmental Management for providing helpful comments that improved our manuscript. This study was supported by a Great Plains Studies Grant (JEM) and funding by the School of Natural Resources at the University of Nebraska-Lincoln (JEM, TLH, and AJT).

\section{References}

Berg, J., Bradshaw, B., Carbone, J., Chojnacky, C., Conroy, S., Cleaves, D., Solomon, R., Yonts-Shepherd, S., 1999. Decision Protocol 2.0. U.S. Forest Service FS-634.

Berkes, F., 2004. Rethinking community-based conservation. Conservation Biology 18, 621-630.

Blann, K., Light, S. S., 2000. The Path of Last Resort: Adaptive Environmental Assessment and Management (AEAM). Adaptive Management Practitioners' Network, Minneapolis, Minnesota.

Blumstein, D. T., 2007. Darwinian decision making: Putting the adaptive into adaptive management. Conservation Biology 21, 552-553.

Carpenter, S. R., 2002. Building an ecology for the long now. Ecology 83, 2069-2083.

Collaborative Adaptive Management Network, 2004; http://www. adaptivemanagement.net (accessed Feb. 26, 2010).

Conroy, M. J., Barker, R. J., Dillingham, P. W., Fletcher, D., Gormley, A. M., Westbrooke, I. M., 2008. Application of decision theory to conservation management: Recovery of Hector's dolphin. Wildlife Research 35, 93-102.

Davis, S. M., Gunderson, L. H., Park, W. A., Richardson, J. R., Mattson, J. E., 1994. Landscape dimension, composition, and function in a changing Everglades ecosystem. In: Davis, S. M., Ogden, J. C. (Eds.), Everglades: The Ecosystem and Its Restoration. St. Lucie Press, Delray Beach, Florida, pp. 419-444.

Field, S. A., Tyre, A. J., Jonzen, N., Rhodes, J. R., Possingham, H. P., 2004. Minimizing the cost of environmental management decisions by optimizing statistical thresholds. Ecology Letters 7, 669-675.

Foundations of Success, 2009. Conceptualizing and Planning Conservation Projects and Programs: A Training Manual. Foundations of Success, Bethesda, Maryland, USA.

Gerber, L. R., Beger, M., McCarthy, M. A., Possingham, H. P., 2005. A theory for optimal monitoring of marine reserves. Ecology Letters 8, 829-837.

Gerber, L. R., Wielgus, J., Sala, E., 2007. A decision framework for the adaptive management of an exploited species with implications for marine reserves. Conservation Biology 21, 1594-1602.

Gregory, R. S., Keeney, R. L., 2002. Making smarter environmental management decisions. Journal of the American Water Resources Association 38, 1601-1612.

Gregory, R., Long, G., 2009. Using structured decision making to help implement a precautionary approach to endangered species management. Risk Analysis 29, 518-532.

Gregory, R., Ohlson, D., Arvai, J., 2006. Deconstructing adaptive management: Criteria for applications to environmental management. Ecological Applications 16, 2411-2425.

Gunderson, L. H., 2000. Ecological resilience-In theory and application. Annual Review of Ecology and Systematics 31, 425-439.

Gunderson, L., 1999. Resilience, flexibility and adaptive management-Antidotes for spurious certitude? Conservation Ecology 3, 7; http://www.consecol.org/vol3/iss1/art7/ (accessed March 30, 2010).

Gunderson, L. H., Holling, C. S. (Eds.), 2002. Panarchy: Understanding Transformations in Human and Natural Systems. Island Press, Washington, D. C.

Gunderson, L., Light, S. S., 2006. Adaptive management and adaptive governance in the Everglades ecosystem. Policy Sciences 39, 323-334.

Gunderson, L., Holling, C., Light, S., 1995. Barriers and Bridges for the Renewal of Regional Ecosystems. Columbia University Press, New York, New York, USA.

Hilborn, R., Walters, C. J., 1981. Pitfalls of environmental baseline and process studies. EIA Review 2, 265-278.

Hobbs, N. T., Hilborn, R., 2006. Alternatives to statistical hypothesis testing in ecology: A guide to self teaching. Ecological Applications 16, 5-19.
Holling, C. S. (Ed.), 1978. Adaptive Environmental Assessment and Management. Wiley, London, UK.

Holling, C. S., 2001. Understanding the complexity of economic, ecological, and social systems. Ecosystems 4, 390-405.

Hughes, T. P., Gunderson, L. H., Folke, C., Baird, A. H., Bellwood, D., Berkes, F., Crona, B., Helfgott, A., Leslie, H., Norberg, J., Nystrom, M., Olsson, P., Osterblom, H., Scheffer, M., Schuttenberg, H., Steneck, R. S., Tengo, M., Troell, M., Walker, B., Wilson, J., Worm, B., 2007. Adaptive management of the great barrier reef and the Grand Canyon world heritage areas. Ambio 36, 586-592.

Johnson, F. A., 2006. Adaptive harvest management and double-loop learning. Transactions of the North American Wildlife and Natural Resources Conference 71, 197-213.

Johnson, F. A., Williams, B. K., 1999. Protocol and practice in the adaptive management of waterfowl harvests. Conservation Ecology 3, 9; http://www.consecol.org/vol3/iss1/art9 (accessed March 30, 2010).

Johnson, F. A., Williams, B. K., Nichols, J. D., Hines, J. E. 1., Kendall, W. L., Smith, G. W., Caithamer, D. F., 1993. Developing an adaptive management strategy for harvesting waterfowl in North America. Transactions of the North American Wildlife and Natural Resources Conference 58, 565-583.

Johnson, F. A., Kendall, W. L., Dubovsky, J. A., 2002. Conditions and limitations on learning in the adaptive management of mallard harvests. Wildlife Society Bulletin 30, 176-185.

Keeney, R. L.,1982. Decision analysis: an overview. Operations Research 30, 803-838.

Lee, K. N., 1999. Appraising adaptive management. Conservation Ecology 3, 3; http://www.consecol.org/vol3/iss2/art3/ (accessed June 13, 2010).

Lee, D. C., Bradshaw, G. A., 1998. Making Monitoring Work for Managers. U. S. Forest Service; http://www.icbemp.gov/spatial/lee_ monitor/begin.html (accessed March 30, 2010).

Levin, S. A.,1999. Fragile Dominion: Complexity and the Commons. Perseus, New York.

Light, S. S., Dineen, J. W., 1994. Water control in the Everglades: A historical perspective. In: Davis, S. M., Ogden, J. C. (Eds.), Everglades: The Ecosystem and Its Restoration. St. Lucie Press, Delray Beach, Florida, pp. 47-84.

McCarthy, M. A., Possingham, H. P., 2007. Active adaptive management for conservation. Conservation Biology 21, 956-963.

McGowan, C. P., Smith, D. R., Nichols, J. D., Martin, J., Sweka, J. A., Lyons, J. E., Niles, L. J., Kalasz, K., Wong, R., Brust, J., Davis, M., 2009. A framework for the adaptive management of Horseshoe Crab harvest in the Delaware Bay constrained by Red Knot conservation. Stock Assessment Report No. 09-02 (Supplement B) of the Atlantic State Marine Fisheries Commission; http://www.asmfc. org/speciesDocuments/horseshoeCrab/annualreports/stockass mtreports/2009DelawareBayARMReport.pdf (accessed June 13, 2010).

Meretsky, V. J., Wegner, D. L., Stevens, L. E., 2000. Balancing endangered species and ecosystems: A case study of adaptive management in Grand Canyon. Environmental Management 25, 579-586.

Merriam-Webster Online Dictionary, 2010. Success. http:// www.merriam-webster.com (accessed Feb. 26, 2010).

Milon, J. W., Kiker, C. F., Lee, D. J., 1997. Ecosystem management and the Florida Everglades: The role of social scientists. Journal of Agricultural and Applied Economics 29, 99-107.

Nichols, J. D., Runge, M. C., Johnson, F. A., Williams, B. K., 2007. Adaptive harvest management of North American waterfowl populations: A brief history and future prospects. Journal of Ornithology 148, 343-349.

Possingham, H. P., 2000. Is environmental research a waste of time? Ecological Management \& Restoration 1, 81-82.

Possingham, H. P., Andelman, S. J., Noon, B. R., Trombulak, S., Pulliam, H. R., 2001. Making smart conservation decisions. In: Orians, G., Soule, M. (Eds.), Research Priorities for Conservation Biology. Island Press, Washington, DC, pp. 1-18.

Powell, L. A., Tyre, A. J., Conroy, M. J., Peterson, J. T., Williams, B. K., in press. Integrating adaptive management into wildlife curricula. Wildlife Professional.

Pulwarty, R. S., Theodore, S. M., 2001. Climate extremes and adaptive management on the Colorado River: Lessons from the 1997-1998 ENSO event. Journal of Environmental Management 63, 307-324.

Reynolds, K., Cunningham, P., Bednar, L., Sanders, M., Foster, M., Olson, R., Schmolt, D., Latham, D., Miller, B., Steffenson, J., 1996. A 
knowledge-based information management system for watershed analysis in the Pacific Northwest U. S. AI Applications 2, 9-22.

Robertson, D. P., Hull, R. B., 2001. Beyond biology: Toward a more public ecology for conservation. Conservation Biology 15, 970-979.

Ruitenbeek, J., Cartier, C., 2001. The Invisible Wand: Adaptive Comanagement as an Emergent Strategy in Complex Bio-economic Systems. Occasional Paper 34. pp. 47. Center for International Forestry Research, Bogor, Indonesia. http://www.cifor.cgiar.org (accessed March 30, 2010).

Runge, M. C., Johnson, F. A., Anderson, M. G., Koneff, M. D., Reed, E. T., Mott, S. E., 2006. The need for coherence between waterfowl harvest and habitat management. The Wildlife Society Bulletin 34, 1231-1237.

Sustainable Ecosystems Institute, 2007. http://sei.org/about.html (accessed Feb. 26, 2010).

Sutherland, W. J., 2006. Predicting the ecological consequences of environmental change: A review of the methods. Journal of Applied Ecology 43, 599-616.
Walters, C. J., 1986. Adaptive Management of Renewable Resources. MacMillan, New York, USA.

Walters, C., 1997. Challenges in adaptive management of riparian and coastal ecosystems. Conservation Ecology 1, 1; http:/ / www.consecol.org/vol1/iss2/art1 (accessed March 30, 2010).

Walters, C. J., Holling, C. S., 1990. Large-scale management experiments and learning by doing. Ecology 71, 2060-2068.

Walters, C., Gunderson, L., Holling, C. S., 1992. Experimental policies for water management in the Everglades. Ecological Applications 2, 189-202.

Williams, B. K., 1996. Adaptive optimization and the harvest of biological populations. Mathematical Biosciences 136, 1-20.

Williams, B. K., Szaro, R. C., Shapiro, C. D., 2007. Adaptive Management: The U.S. Department of the Interior Technical Guide. Adaptive Management Working Group, U.S. Department of the Interior, Washington, DC.

Appendix A:
Articles used in the analysis and distributed by school of thought followed by success category.

\section{Resilience Experimentalist School of Thought}

\section{Success Category: Theory}

Berkes, F., Colding, J., Folke, C., 2000. Rediscovery of traditional ecological knowledge as adaptive management. Ecological Applications 10, 1251-1262.

Berkes, F., 2004. Rethinking community-based conservation. Conservation Biology 18, 621-630.

Blumenthal, D., Jannink, J., 2000. A classification of collaborative management methods. Conservation Ecology 4, 13 http://www. consecol.org/vol4/iss2/art13/. Accessed 30 March 2010.

Blumstein, D.T., 2007. Darwinian decision making: putting the adaptive into adaptive management. Conservation Biology 21, 552-553.

Bradshaw, G. A., Borchers, J.G., 2000. Uncertainty as information: narrowing the science-policy gap. Conservation Ecology 4, 7 http://www.consecol.org/vol4/iss1/art7/. Accessed 30 March 2010.

Keough, H.L., Blahna, D.J., 2006. Achieving integrative, collaborative ecosystem management. Conservation Biology 20, 1373-1382.

Koontz, T.M., Bodine, J., 2008. Implementing ecosystem management in public agencies: lessons from the U.S. Bureau of Land Management and the Forest Service. Conservation Biology 22, 60-69.

Sutherland, W.J., 2006. Predicting the ecological consequences of environmental change: a review of the methods. Journal of Applied Ecology 43, 599-616.

Wilhere, G.F., 2002. Adaptive management in habitat conservation plans. Conservation Biology 16, 20-29.

\section{Success Category: Suggest}

Bax, N.J, Thresher, R.E., 2009. Ecological, behavioral, and genetic factors influencing the recombinant control of invasive pests. Ecological Applications 19, 873-888.

Bennett, L.T., Adams, M.A., 2004. Assessment of ecological effects due to forest harvesting: approaches and statistical issues. Journal of Applied Ecology 41, 585-598.

Bierwagen, B.G., Thomas, R., Kane, A., 2008. Capacity of management plans for aquatic invasive species to integrate climate change. Conservation Biology 22, 568-574.

Converse, S.J., White, G.C., Farris, K.L., Zack, S., 2006. Small mammals and forest fuel reduction: National-scale responses to fire and fire surrogates. Ecological Applications 16, 1717-1729.

Curtin, C., Western, D., 2008. Grasslands, people, and conservation: Over-the-horizon learning exchanges between African and American pastoralists. Conservation Biology 22, 870-877.
Doak, D.F., Estes, J.A., Halpern, B.S., Jacob, U., Lindberg, D.R. Lovvorn, J., Monson, D.H., Tinker, M.T., Williams, T.M., Wootton, J.T., Carroll, I., Emmerson, M., Micheli, F., Novak, M., 2008. Understanding and predicting ecology dynamics: are major surprises inevitable? Ecology 89, 952-961.

Frederiksen, M., Lebreton, J.D., Bregnballe, T., 2001. The interplay between culling and density-dependence in the great cormorant: a modeling approach. Journal of Applied Ecology 38, 617-627.

Lindenmayer, D.B., Margules, C.R., Botkin, D.B., 2000. Indicators of biodiversity for ecologically sustainable forest management. Conservation Biology 14, 941-950.

Mac Nally, R., Fleishman, E., Murphy, D.D., 2004. Influence of temporal scale of sampling on detection of relationships between invasive plants and the diversity patterns of plants and butterflies. Conservation Biology 18, 1525-1532.

Martin, K.L., Kirkman, L.K., 2009. Management of ecological thresholds to re-establish disturbance-maintained herbaceous wetlands of the south-eastern USA. Journal of Applied Ecology 46, 906-914

McCarthy, M.A., Parris, K.M., 2008. Optimal marking of threatened species to balance benefits of information with impacts of marking. Conservation Biology 22, 1506-1512.

Redfield, G.W., 2000. Ecological research for aquatic science and environmental restoration in south Florida. Ecological Applications 10, 990-1005.

Robinson, C.J., Smyth, D., Whitehead, P.J., 2005. Bush tucker, bush pets, and bush threats: Cooperative management of feral animals in Australia's Kakadu National Park. Conservation Biology 19, 1385-1391.

Sauer, J.R., Knutson, M.G., 2008. Objectives and metrics for wildlife monitoring. Journal of Wildlife Management 72, 1663-1664.

Toledo, V. M., Ortiz-Espejel, B., Cortés, L., Moguel, P., Ordoñez, M.D.J., 2003. The multiple use of tropical forests by indigenous peoples in Mexico: a case of adaptive management. Conservation Ecology 7: 9 http://www.consecol.org/vol7/iss3/art9/. Accessed 30 March 2010.

Warburton, B., Norton, B.G., 2009. Towards a Knowledge-based ethic for lethal control of nuisance wildlife. Journal of Wildlife Management 73, 158-164.

Wasserberg, G., Osnas, E.E., Rolley, R.E., Samuel, M.D., 2009. Host culling as an adaptive management tool for chronic wasting disease in white-tailed deer: a modeling study. Journal of Applied Ecology $46,457-466$.

Zweig, C.L., Kitchens, W.M., 2009. Multi-state succession in wetlands: a novel use of state and transition models. Ecology 90, 1900-1909. 
Success Category: Framework

Barrows, C.W., Swartz, M.B., Hodges, W.L., Allen, M.F., Allen, M.F., Rotenberry, J.T., Li, B., Scott, T.A., Chen, X., 2005. A framework for monitoring multiple-species conservation plans. Journal of Wildlife Management 69, 1333-1345.

Bearlin, A.R., Schreiber, E.S.G., Nicol, S.J., Starfield, A.M., Todd, C.R., 2002. Identifying the weakest link: simulating adaptive management of the reintroduction of a threatened fish. Canadian Journal of Fisheries and Aquatic Sciences 59, 1709-1716.

Dimond, W.J., Armstrong, D.P., 2007. Adaptive harvesting of source populations for translocation: a case study with New Zealand Robins. Conservation Biology 21, 114-124.

Gerber, L.R., Wielgus, J., Sala, E., 2007. A decision framework for the adaptive management of an exploited species with implications for marine reserves. Conservation Biology 21, 1594-1602.

Gray, A. N. 2000. Adaptive ecosystem management in the Pacific Northwest: a case study from coastal Oregon. Conservation Ecology 4, 6 http://www.consecol.org/vol4/iss2/art6/ . 30 March 2010.

Irwin, E.R., Freeman, M.C., 2002. Proposal for adaptive management to conserve biotic integrity in a regulated segment of the Tallapoosa River, Alabama, U.S.A. Conservation Biology 16, 1212-1222.

Jacobson, S.K., Morris, J.K., Sanders, J.S., Wiley, E.N., Brooks, M., Bennetts, R.E., Percival, H.F., Marynowski, S., 2006. Understanding barriers to implementation of an adaptive land management program. Conservation Biology 20, 1516-1527.

Long, J., A. Tecle, and B. Burnette. 2003. Cultural foundations for ecological restoration on the White Mountain Apache Reservation. Conservation Ecology 8, 4 http://www.consecol.org/vol8/iss1/ art4/. Accessed 30 March 2010.

Lyons, J.E., Runge, M.C., Laskowski, H.P., Kendall, W.L., 2008. Monitoring in the context of structured decision-making and adaptive management. Journal of Wildlife Management 72, 1683-1692.

Marmorek, D. and C. Peters. 2001. Finding a PATH toward scientific collaboration: insights from the Columbia River Basin. Conservation Ecology 5, 8 http://www.consecol.org/vol5/iss2/art8/. Accessed 30 March 2010.

Moore, A.L., Hauser, C.E., McCarthy, M.A., 2008. How we value the future affects our desire to learn. Ecological Applications 18, 1061-1069.

Richter, B.D., Mathews, R., Harrison, D.L., Wigington, R., 2003. Ecologically sustainable water management: managing river flows for ecological integrity. Ecological Applications 13, 206-224.

Salafsky, N., Margoluis, R., Redford, K.H., Robinson, J.G., 2002. Improving the practice of conservation: a conceptual framework and research agenda for conservation science. Conservation Biology $16,1469-1479$.

Walters, C., J. Korman, L. E. Stevens, and B. Gold. 2000. Ecosystem modeling for evaluation of adaptive management policies in the Grand Canyon. Conservation Ecology 4, 1 http://www.consecol. org/vol4/iss2/art1/. Accessed 30 March 2010.

\section{Success Category: Implement}

Gregory, R., Ohlson, D., Arvai, J., 2006. Deconstructing adaptive management: criteria for applications to environmental management. Ecological Applications 16, 2411-2425.

Hagmann, J. R., E. Chuma, K. Murwira, M. Connolly, and P. Ficarelli. 2002. Success factors in integrated natural resource management R\&D: lessons from practice. Conservation Ecology 5, 29 http:// www.consecol.org/vol5/iss2/art29/. Accessed 30 March 2010.

Hansen, G.J.A., Jones, M.L., 2008. A rapid assessment approach to prioritizing streams for control of Great Lakes sea lampreys (Petromyzon marinus): a case study in adaptive management. Canadian Journal of Fisheries and Aquatic Sciences 65, 2471-2484.

Molina, R., Marcot, B.G., Lesher, R., 2006. Protecting rare, old-growth, forest-associated species under the survey and manage program guidelines of the Northwest Forest Plan. Conservation Biology 20, 306-318.

Shannon, J.P., Blinn, D.W., McKinney, T., Benenati, E.P., Wilson, K.P., O'Brien, C., 2001. Aquatic food base response to the 1996 test flood below Glen Canyon Dam, Colorado River, Arizona. Ecological Applications 11, 672-685.

\section{Success Category: Mention}

Beier, P., 2003. Adaptive management and SCB's evaluation of species recovery plans. Conservation Biology 17, 653-655.

Carpenter, S.R., 2002. Building an ecology of the long now. Ecology 83, 2069-2083.

Clark, J.A., Hoekstra, J.M., Boersma, P.D., Kareiva, P., 2003. Adaptive management and $\mathrm{SCB}^{\prime}$ s evaluation of species recovery plans. Conservation Biology 17, 655.

Stansfield, B. 2003. Adapative management and trial-and-error learning. Conservation Ecology 7: 10 http://www.consecol.org/ vol7/iss1/resp10/. Accessed 30 March 2010.

\section{Decision Theoretic School of Thought}

\section{Success Category: Theory}

Dorazio, R.M., Johnson, F.A., 2003. Bayesian inference and decision theory - A framework for decision making in natural resource management. Ecological Applications 13, 556-563.

Runge, M.C., Johnson, F.A., 2002. The importance of functional form in optimal control solutions of problems in population dynamics. Ecology 83, 1357-1371.

\section{Success Category: Suggest}

Buckley, Y.M., 2008. The role of research for integrated management of invasive species, invaded landscapes and communities. Journal of Applied Ecology 45, 397-402.

Clarke, M.F., 2008. Catering for the needs of fauna in fire management: science or just wishful thinking? Wildlife Research 35, 385-394.

Foster, S.J., Vincent, A.C.J., 2005. Enhancing sustainability of the international trade in seahorses with a single minimum size limit. Conservation Biology 19, 1044-1050.

Runge, M.C., Sauer, J.R., Avery, M.L., Blackwell, B.F., Koneff, M.D., 2009. Assessing allowable take of migratory birds. Journal of Wildlife Management 73, 556-565.

Shea, K., Kelly, D., Sheppard, A.W., Woodburn, T.L., 2005. Contextdependent biological control of an invasive thistle. Ecology 86, 3174-3181.

Wolf, N., Mangel, M., 2008. Multiple hypothesis testing and the declining-population paradigm in Stellar sea lions. Ecological Applications 18, 1932-1955.

\section{Success Category: Framework}

Bogich, T., Shea, K., 2008. A state-dependent model for the optimal management of an invasive metapopulation. Ecological Applications 18, 748-761.

Conroy, M.J., Barker, R.J., Dillingham, P.W., Fletcher, D., Gormley, A.M., Westbrooke, I.M., 2008. Application of decision theory to conservation management: recovery of Hector's dolphin. Wildlife Research 35, 93-102.

Hauser, C.E., Possingham, H.P., 2008. Experimental or precautionary? Adaptive management over a range of time horizons. Journal of Applied Ecology 45, 72-81.

Martin, J., Runge, M.C., Nichols, J.D., Lubow, B.C., Kendall, W.L., 2009. Structured decision making as a conceptual framework to identify thresholds for conservation and management. Ecological Applications 19, 1079-1090.

McCarthy, M.A., Possingham, H.P., 2007. Active adaptive management for conservation. Conservation Biology 21, 956-963.

Morellet, N., Gaillard, J., Hewison, A.J.M., Ballon, P., Boscardin, Y., Duncan, P., Klein, F., Maillard, D., 2007. Indicators of ecological change: new tools for managing populations of large herbivores. Journal of Applied Ecology 44, 634-643. 
Rout, T.M., Hauser, C.E., Possingham, H.P., 2009. Optimal adaptive management for the translocation of a threatened species. Ecological Applications 19, 515-526.

Shea, K., Possingham, H.P., Murdoch, W.W., Roush, R., 2002. Active adaptive management in insect pest and weed control: intervention with a plan for learning. Ecological Applications 12, 927-936.

\section{Success Category: Implement}

Armstrong, D.P., Castro, I., Griffiths, R., 2007. Using adaptive management to determine requirements of re-introduced populations: the case of the New Zealand hihi. Journal of Applied Ecology 44, 953-962.

Conn, P.B., Kendall, W.L., 2004. Evaluating Mallard adaptive management models with time series. Journal of Wildlife Management 68, 1065-1081.

Cruz, F., Carrion, V., Campbell, K.J., Lavoie, C., Donlan, C.J., 2009. Bioeconomics of large-scale eradication of feral goats from Santiago Island, Galápagos. Journal of Wildlife Management 73, 191-200.

Kilpatrick, A.M., Gillin, C.M., Daszak, P., 2009. Wildlife-livestock conflict: the risk of pathogen transmission from bison to cattle outside Yellowstone National Park. Journal of Applied Ecology 46, 476-485.

Linacre, N.A., Stewart-Oaten, A., Burgman, M.A., Ades, P.K., 2004. Incorporating collateral data in conservation biology. Conservation Biology 18, 768-774.

Lynam, T., F. Bousquet, C. Le Page, P. d'Aquino, O. Barreteau, F. Chinembiri, and B. Mombeshora. 2002. Adapting science to adaptive managers: spidergrams, belief models, and multi-agent systems modeling. Conservation Ecology 5: 24 http://www. consecol.org/vol5/iss2/art24/. Accessed 30 March 2010.

Shorey, R.I., Scribner, K.T., Prince, H.H., Kravchenko, A.N., Luukkonen, D.R., Padding, P.I., 2007. Genetic analysis of standardized collections of Cackling and Canada Goose harvests. Journal of Wildlife Management 71, 1458-1466.

\section{Success Category: Mention}

Mertens, S.K., Yearsley, J.M., van den Bosch, F., Gilligan, C.A., 2006. Transient population dynamics in periodic matrix models: methodology and effects of cyclic permutations. Ecology 87, 23382348.

\section{School of Thought: Other}

\section{Success Category: Theory}

Clark, J.A., Harvey, E., 2002. Assessing multi-species recovery plans under the Endangered Species Act. Ecological Applications 12, 655-662.

Hobbs, N.T., Hilborn, R., 2006. Alternatives to statistical hypothesis testing in ecology: a guide to self teaching. Ecological Applications 16, 5-19.

Hulme, P.E., 2005. Adapting to climate change: is there scope for ecological management in the face of a global threat? Journal of Applied Ecology 42, 784-794.

Pandey, D.N., 2003. Cultural resources for conservation science. Conservation Biology 17, 633-635.

Parr, C.L., Andersen, A.N., 2006. Patch mosaic burning for biodiversity conservation: a critique of the pyrodiversity paradigm. Conservation Biology 20, 1610-1619.

Stem, C., Margoluis, R., Salafsky, N., Brown, M., 2005. Monitoring and evaluation in conservation: a review of trends and approaches. Conservation Biology 19, 295-309.

\section{Success Category: Suggest}

Aburto-Oropeza, O., Sala, E., Paredes, G., Mendoza, A., Ballesteros, E., 2007. Predictability of reef fish recruitment in a highly variable nursery habitat. Ecology 88, 2220-2228.
Bar-David, S., Saltz, D., Dayan, T., 2005. Predicting the spatial dynamics of a reintroduced population: the Persian Fallow Deer. Ecological Applications 15, 1833-1846.

Cinner, J.E., McClanahan, T.R., Graham, N.A.J., Pratchett, M.S., Wilson, S.K., Raina, J., 2009. Gear-based fisheries management as a potential adaptive response to climate change and coral mortality. Journal of Applied Ecology 46, 724-732.

Davis, G.E., 2005. Science and society: Marine reserve design for the California Channel Islands. Conservation Biology 19, 1745-1751.

Goldingay, R.L., Stevens, J.R., 2009. Use of artificial tree hollows by Australian birds and bats. Wildlife Research 36, 81-97.

Hirzel, A.H., Posse, B., Oggier, P., Crettenand, Y., Glenz, C., Arlettaz, R., 2004. Ecological requirements of reintroduced species and the implications for release policy: the case of the bearded vulture. Journal of Applied Ecology 41, 1103-1116.

Muller, B., Linstadter, A, Frank, K., Bollig, M., Wissel, C., 2007. Learning from local knowledge: Modeling the pastoral-nomadic range management of the Himba, Namibia. Ecological Applications $17,1857-1875$.

Olexa, E.M., Gogan, P.J.P., 2007. Spatial population structure of Yellowstone bison. Journal of Wildlife Management 71, 1531-1538.

Rempel, L.L., Church, M., 2009. Physical and ecological response to disturbance by gravel mining in a large alluvial river. Canadian Journal of Fisheries and Aquatic Sciences 66, 52-71.

Robertson, B.C., Gemmell, N.J., 2004. Defining eradication units to control invasive pests. Journal of Applied Ecology 41, 1042-1048.

Schmiegelow, F.K.A., Stepnisky, D.P., Stambaugh, C.A., Koivula, M., 2006. Reconciling salvage logging of boreal forests with a naturaldisturbance management model. Conservation Biology 20, 971-983.

Stephens, S.L., Ruth, L.W., 2005. Federal forest-fire policy of the United States. Ecological Applications 15, 532-542.

Theobald, D.M., Spies, T., Kline, J., Maxwell, B., Hobbs, N.T., Dale, V.H., 2005. Ecological support for rural land-use planning. Ecological Applications 15, 1906-1914.

Treves, A., Karanth, K.U., 2003. Human-carnivore conflict and perspectives on carnivore management worldwide. Conservation Biology 17, 1491-1499.

Vanderwel, M.C., Malcolm, J.R., Mills, S.C., 2007. A meta-analysis of bird responses to uniform partial harvesting across North America. Conservation Biology 21, 1230-1240.

Vester, H.F.M., Lawrence, D., Eastman, J.R., Turner II, B.L., Calme, S., Dickson, R., Pozo, C., Sangermano, F., 2007. Land change in the southern Yucatan and Calakmul Biosphere Reserve: Effects on habitat and biodiversity. Ecological Applications 17, 989-1003.

\section{Success Category: Framework}

Andow, D.A., Ives, A.R., 2002. Monitoring and adaptive resistance management. Ecological Applications 12, 1378-1390.

\section{Success Category: Implement}

Cummings, J., Reid, N., Davies, I., Grant, C., 2005. Adaptive restoration of sand-mined areas for biological conservation. Journal of Applied Ecology 42, 160-170.

\section{Against}

Hinrichsen, R. A. 2000. Are there scientific criteria for putting shortterm conservation ahead of learning? No. Response to Kai N. Lee 1999: "Appraising Adaptive Management". Conservation Ecology 4: 7 http://www.consecol.org/vol4/iss1/resp7/. Accessed 30 March 2010.

Jager, H.I., 2005. Genetic and demographic implications of aquaculture in white sturgeon (Acipenser transmontanus) conservation. Canadian Journal of Fisheries and Aquatic Sciences 62, 1733-1745.

Prato, T., 2005. Accounting for uncertainty in making species protection decisions. Conservation Biology 19, 806-814. 